\title{
Africa and the Challenges of Globalisation: Agenda for Action
}

\section{S K B Asante}

Former Principal Regional Advisor, UNECA, Ethiopia

\begin{abstract}
As we enter the brave new world of the 21 st century, a critical analysis of Africa's position in the globalising world economy with a view to grasping fully the policy challenges that lie ahead has become increasingly necessary. To this end, the paper addresses not only the challenges which globalisation poses to Africa; it also draws attention to the general denunciation, in Africa, of the phenomenon of globalisation. It is argued that while Africa cannot resist globalisation, it can at least make adjustments in economic policies that will enable the African countries to achieve gains while conceding losses. Hence an agenda for action has been provided to highlight a number of key areas on which policy should focus attention.
\end{abstract}

JEL 019

\section{INTRODUCTION}

The growing interest in both official and private quarters in the phenomenon of globalisation and its companion, the process of economic liberalisation, as a dominant force in the last decade of the twentieth century, has generated much thinking and analysis about its origin, its impact on economies and societies, and on the pattern of its likely evolution. Although much publicity has surrounded some of the analysis, it is clear that these multifaceted phenomena have important implications, which governments, businesses and analysts all over the world must address. Much of the analysis and thinking has focused on the more visible aspects of globalisation, notably, the sea changes taking place in the pattern of production, pace of diffusion of knowledge and information and in the convergence of factor markets.

Less well understood and analysed, however, is the challenge of the phenomenon of marginalisation which globalisation poses to the developing countries, particularly those in Africa, which are at the periphery of global processes and have been so over a very long period. Marginalisation in this context connotes the decline in the African countries' share of world trade, capital flows and pro- 
duction to negligible levels, with severe consequences for their development and living standards. Given the importance of trade and foreign direct investment (FDI) flows in stimulating and facilitating technological innovations, the implication of this marginalisation is that African countries and the other least developed countries will fall even further behind the rest of the world in terms of their technological capacities. Questions such as whether globalisation will assist their integration in the world economy or whether the new challenges will further weaken their already precarious links are far from academic but are at the centre of the development debate. There is a danger that the fragile economic and social position, which characterises many of the African countries, will deteriorate further unless major efforts are made by them, supported by the international community, to adjust to the challenges of globalisation and liberalisation.

This paper attempts to address some of the challenges which globalisation poses to Africa. It then outlines the appropriate policies that would be required to meet the challenges. This has become increasingly necessary as, in the absence of appropriate policy responses from the African countries and the international community, globalisation may do little to alleviate the trend towards their marginalisation from the world economy and may even accentuate it. After this introductory section, Section II focuses attention on the globalisation process and its key features, including the causes and forces behind this process, while Section III analyses the position of Africa in the globalising world economy. More importantly, the section highlights the challenges which globalisation poses to the African states. In Section IV, an agenda for action to meet the challenges of globalisation and consequently facilitate Africa's march towards claiming the 21 st century is provided. Section V concludes with a brief highlight on Africa's prospects in meeting the challenges posed by globalisation.

\section{THE GLOBALISATION PROCESS}

Globalisation has become an outstanding phenomenon of our times. The term, which is used to describe the shape of the world economy today, has become fashionable but its meaning and implications, particularly for developing countries, are far from clear. It has raised such perplexing questions as: What really is globalisation? Why has globalisation occurred? Or, what causes globalisation? How, if at all, has globalisation generated social change? What benefits and harms have flowed from globalisation? Or, as Paul Streeten recently put it, is globalisation a threat to humanity, or its salvation (Streeten, 1998: 13)? Insofar as globalisation can have ill effects, how might they be avoided? 
It is not our intention to respond to all these questions, which grip much contemporary political debate. Suffice it to say that globalisation as a term refers to the growing interaction of countries in world trade, foreign direct investment and capital markets. This phenomenon is shaping a new era of interaction among nations, economies and people. Specifically, it is increasing the contacts between people across national boundaries - in economy, in technology, in culture, and in govemance. Briefly stated, globalisation is characterised by four types of changes. First it involves a stretching of social, political, and economic activities across frontiers, regions and continents. Second, it is marked by the intensification, or the growing magnitude, of interconnectedness and flows of trade, investment, finance, migration, and culture. Third, it can be linked to a speeding up of global interactions and processes, as the development of worldwide systems of transport and communication increases the velocity of the diffirsion of ideas, goods, information, capital, and people. And fourth, the growing extensity, intensity, and velocity of global interactions can be associated with their deepening impact such that the effects of distant events can be highly significant elsewhere and specific local developments can come to have considerable global consequences. In this sense, the boundaries between domestic matters and global affairs become increasingly fluid. Globalisation, in short, can be thought of as the widening, intensifying, speeding up, and growing impact of worldwide interconnectedness (Held \& McGrew, 2001: 324).

The global economy has become more liberalised as almost all countries throughout the world have adopted market-oriented policies entailing the reduction of government intervention and the privatisation of state-owned assets. While liberalisation has contributed to global economic integration by removing barriers to trade and investment, it is also a response to it, as governments' ability to control economic events within their own borders has progressively diminished. Globalisation therefore has profound implications for states. Everywhere the imperative to liberalise has demanded a shrinking of state involvement in national life, producing a wave of privatisations of public enterprises and, generally, job cuts. And everywhere the opening of financial markets has limited governments' ability to run deficits - requiring them to slash health spending and food subsidies that benefit poor people. Thus the comforting illusion that states could exist as islands and successfully manage their economies regardless of the dictates of global markets has been cruelly shattered.

Another principal issue in debates about globalisation concerns chronology. Is the spread of global relations new to contemporary history? Or did the trend start several generations, centuries or even millennia ago? Or is globalisation a cyclical phenomenon that comes and goes from time to time? What appears certain is that the phenomenon of globalisation is not new since trade and foreign direct investment, the most commonly used indicators of globalisation, grew 
rapidly even in the nineteenth and early twentieth centuries. The geographical dispersion of economic activity has been taking place for decades if not centuries. If globalisation is not a new phenomenon, does the current phase of globalisation differ from the earlier phases? The current phase is no doubt qualitatively different from that of the earlier period, that is, from the mid-1880s to the end of World War I. A larger part of the world and a larger number of independent countries are participating in it. New technological advances have sharply reduced transportation, telecommunication, and computation costs, greatly increasing the ease with which national markets may be integrated at the global level. Economic distances have shrunk and coordination problems have diminished to such an extent that in many cases it has become an efficient method of industrial organisation for a firm to locate different phases of production in different parts of the world. The structure of foreign trade has increasingly become intra-industry and intra-firm, and FDI serves as an important vehicle of globalisation. More and more, countries depend on each other for technology transfer and learn from each other manufacturing methods, modes of organisation, marketing, and product design. The various elements of globalisation - trade, direct investment flows, technology transfers - have become more closely linked and interconnected, and the world economy is becoming, more and more, the relevant context for economic decisions.

Although the causes and the forces behind the process of globalisation are well known, three of them, which particularly played a crucial part in giving a momentum to this process, are worth highlighting. One of them is the political change that has taken place recently on the world stage, following the break-up of the Communist countries and the end of the bi-polar world. It gave a new ascendancy to the capitalist countries of the West to pursue the policies, the agenda and the goals that they have always believed in. The demise of the communist state and the command economy opened the way for dismantling state control over economic decision-making. It also permitted the resurgence of free market economy policies and deregulation of markets, including liberalisation of international transactions. These policy changes provided further impetus to the free flow of resources within the global economy and across national boundaries.

The second factor relates to the role played by many international institutions in creating the framework for the progress of globalisation and liberalisation. A case in point is the role played by the World Trade Organisation (WTO). It not only took the process of opening up markets to new levels, but also introduced and brought into its ambit a whole new series of issues that had not yet figured in the agenda of international liberalisation, such as negotiations on investment, services, intellectual properties and so on. The Bretton Woods institutions also contributed to the spread of the globalisation and liberalisation phenomenon, as 
evidenced in their introduction of major changes in the economies of the developing countries through what they call structural adjustment programmes, the core of which is encouragement to these countries to allow their economies to be merged with those of the outside world. With this in view they are asked to reduce the barriers to investment and deregulate their economies (Gamani, 1999: 15).

The third striking development has been the spectacular advances in communications technology, which has brought every part of the globe within easy reach, made it possible for people to come into close and rapid contact with each other, for funds to flow across most borders at a moment's notice, and for investment houses established in different parts of the world to maintain contacts with their head offices. Events in one comer of the world are very quickly reported in all other parts, sometimes even as they happen. Similarly, their effects are quickly transmitted across national boundaries in a process sometimes referred to as the contagion effect. Hence the frequent references to our world today as the global village.

It has been argued in recent official reports and studies (UNCTAD, 1996; IMF, 1997) that the pressures of globalisation, especially in the past decade or so, have served to accentuate the benefits of good policies and the costs of bad policies. Countries that align themselves with the forces of globalisation and embrace the reforms needed to do so, liberalising markets and pursuing disciplined macroeconomic policies, are likely to put themselves on a path of convergence with the advanced economies, following the successful Asian newly industrialised economies (NIEs). These countries may expect to benefit from trade, gain global market share, and be increasingly rewarded with larger private capital flows. Countries that do not adopt such policies are likely to face declining shares of world trade and private capital flows, and to find themselves falling behind in relative terms. Evidently, therefore, globalisation is a double-edged sword, with both opportunities and threats. For some countries, globalisation will present unprecedented opportunities for growth and prosperity. For others, globalisation could mean what a recent magazine (African Business, 2000: 8) has termed "economic enslavement". Where does Africa fit into all this? How does the African leadership view the process of globalisation, which, as we enter into the new millennium, will continue to dominate the political and economic landscape, resulting in an unparalleled surge in international trade and financial flows across borders and opening up of the domestic markets of an increasing number of developing countries? 


\section{AFRICA IN THE GLOBALISING ECONOMY}

Virtually from the Limpopo River to the Nile, Africa has been unanimous in its denunciation of globalisation and the challenges it poses to the region. A case in point was the general condemnation of the process of globalisation at the recent Southern African International Dialogue Forum held in the Mozambique capital of Maputo. At the Forum, Uganda's President Yoweri Museveni labelled globalisation as a new form of oppression, stressing that "the new world order is merely the same as old oppression of the developing nations by the West" (African Business, 2000: 9). In the same vein, President Robert Mugabe of Zimbabwe stressed that Africa did not yet have the capacity to enter the global village, maintaining that the "continent is still grappling to put up basic necessities such as good roads, railways and transportation" (Nevin, 2000: 8). In general, African critics have argued that globalisation - driven by high technology - is just "another form of colonialism", particularly since African economies are so dependent on the prices of raw commodities. Africa's bargaining power has evaporated due to the instant availability of alternative supplies from Asia, South America and even the developing nations of the ex-Soviet empire. It is further stressed that globalisation is spawning a new breed of commercial behemoths and Africa is in danger of being dominated by such giants who gain a stranglehold monopoly.

The general African denunciation of globalisation was reinforced by President Olusegun Obasanjo of Nigeria at the Thirty-fifth Ordinary Summit of the Organisation of African Unity (OAU) held in Algiers, Algeria, in July 1999, when he concluded that the "tragedy is that all of us here are witnessing how Africa is being bypassed and its marginalisation turning into de-linkage" (AEC Newsletter, 1999: 5). To many African and Third World leaders, therefore, globalisation is nothing short of neo-imperialism. It may well be the defining force in contemporary society, but it looks and smells like good old imperialism in much finer clothes and with a good deal more power, dangling the carrot of imperialism and wielding a bigger stick. As Samir Amin highlighted at a recent Beijing conference, "globalisation is an ideology that masqueraded as a theory, when in fact it is an expression of the hegemony of the triad, that is, the United States, European Union and Japan" (Inside AISA, 2000: 2). It is a combination of opportunities and challenges: opportunities for those that already have the necessary financial and communication infrastructure in place; and challenges for those in Africa that are still in the process of re-tooling their economies to meet trade liberalisation requirements.

In this regard, South Africa's ambiguous attitudes about globalisation are worth noting. In a survey of the attitudes of the South African elite vis-à-vis globalisation, Phillip Nel argues that the South African policy elite displays ambiguous 
attitudes about whether to accept or resist globalisation. At the heart of this lies the fact that the main partners in the Government of National Unity have opposing views of desirable macro-economic scenarios in South Africa (Nel, 1999: 22). It is not surprising, therefore, that south of the Limpopo river, South Africa finds itself wearing two hats, thus making its stand in this virtual pan-African indictment of the globalisation process disturbingly ambiguous. South Africa badly wants its place in the global village, seeing acceptance by Western economies as the road to its own financial independence. Its problem is to court the well-heeled Westemers, while at the same time being seen to share the antiglobalisation indignation of its African kith and kin. South Africa finds that a difficult tightrope on which to keep its balance. It is steaming ahead into the information age, becoming a world leader in some sectors. Its information technology (IT) companies are venturing deeper into Africa in an attempt to hasten its information coming of age.

While the pan-African denunciation of the globalisation process and the ambiguous position of South Africa on the subject are worth noting, the fact remains that Africa and, indeed the developing world in general, cannot escape globalisation whether we like it or not, neither can we wish it away. In this regard, the exact position of Africa in the globalising world economy is of prime importance in any endeavour to fully grasp the policy challenges that lie ahead as we enter the 21 st century. This is particularly necessary as from every point of view, the African state is a peripheral state within the global economy. Many African countries are small, poor and land-locked. Thirty-four out of forty-eight least developed countries in the world are in Africa. Out of the 174 countries ranked in the United Nations Development Programme's Human Development Report 1998, the bottom 30 includes 25 African states (UNDP, 1998: 128-130).

Although growth and exports have recovered in recent years, per capita incomes are still low. Excluding South Africa, as a recent illuminating study has highlighted, Africa's "average income per capita averaged just \$315 in 1997 when converted at market exchange rates". The region's total income is not much more than Belgium's, and is divided among 48 countries with median GDP of just over $\$ 2$ billion - about the output of a town of 60,000 in a rich country. "More than 40 per cent of Africa's 600 million people live below the internationally recognised poverty line of $\$ 1$ a day, with incomes averaging just $\$ 0.65$ a day in purchasing power parity terms" (World Bank, 2000: 7, 9-10). Savings and investment remain equally low while debt and service obligations continue to rise. By the end of 1997 foreign debt represented a burden of more than 80 per cent of GDP in net per cent value terms. High population growth rates have contributed to the erosion of recent gains from higher GDP growth rates. The weakness of Africa's global integration, which constitutes a series of challenges 
to the region, is evident in its falling share in the following important sectors, which feature the globalisation process.

\section{Challenges to Africa}

\section{The Challenge of Expansion and Liberalisation of International Trade}

A major hallmark of globalisation is the liberalisation of trade policies, and the expansion of international merchandise trade. For example, as Chinery-Hesse notes, the value of world merchandise trade had more than doubled from a little more than US\$2 trillion, in 1980 , to US\$4 trillion in 1994. Countries that diversified their exports and opened their economies to imports and investment have grown faster than countries that continue to export only basic commodities and raw materials, or that maintain protectionist policies (Chinery-Hesse, 1997: 125). The available statistics suggest that Africa is in the latter category, as it is visibly stuck at the periphery of the globalising world economy. The region's current position in the global economy is characterised by a small and declining share of world trade, and concentration on the production of primary exports and importation of non-primary products. Africa's share of world trade varied from 4.1 per cent to 4.9 per cent from 1960-65, fluctuated around 4.4 per cent during the 1970s and declined to 2-3 per cent in the 1990s. Its share of world exports fell from 4.7 per cent in 1975 to 2.0 per cent in 1990; the share of the least developed African countries suffered a more drastic fall, from 0.6 per cent to 0.2 per cent (UNIDO, 1993). Against this background, African countries are faced with the challenge of striving to reduce their protectionist measures and reform the trade policies that have been a major factor in Africa's declining share in world trade over the past decade. African countries should also reverse the trend of export concentration experienced during the past three decades, through greater efforts at diversifying the agricultural export base and the promotion of processed agricultural products.

A closely related challenge is the intensified competition, which the African countries can expect from other producers of manufactured exports and primary commodities, following liberalisation of world trade and increased interdependence of national economies. Unless they take appropriate measures, the African countries may continue to lose world-market share to other countries, even in traditional export commodities such as cocoa, palm oil and coffee. Given that the diversification of production and exports is a medium- to long-term undertaking, the African countries will have to improve their international competitiveness in traditional exports too. This will require appropriate macro-economic and sector policies - namely competitive exchange rates and measures to reduce the domestic costs of production - as well as improved competitiveness in non- 
price factors such as more efficient marketing services, and this includes using the information highway.

The other challenge facing the African countries in the liberalisation of international trade is related to the phasing out of the preferences under the Uruguay Round accord. Already increased globalisation has seen most African countries suffer under various agreements and treaties, besides the Uruguay Round, and the June 2000 Cotonou Partnership Agreement between the European Union $(\mathrm{EU})$ and the African Caribbean and Pacific (ACP) countries points to many of the problems ahead. In most areas of trade where ACP countries had hitherto enjoyed some concessions in the previous Lome Agreement, these will now be abolished a few years after the members ratify the Partnership Agreement (Otabil, 2000).

\section{The Challenge of Investment}

Despite liberalisation of the investment codes of many countries, Africa is confronted with a challenge of marginalisation in terms of FDI flows. The levels of private and public investment have been modest, even in African countries with the most successful reforms. As Wangwe and Musonda have recently argued, investment as a percentage of GDP declined significantly between the 1970 s and the 1990 s, from nearly 26 per cent to a little over 16 per cent (Wangwe \& Musonda, 1998: 154). Most FDI in Africa is concentrated in a small number of countries that are endowed with natural resources, especially oil. Africa has been largely left outside the fast growing capital markets. Since 1980, FDI in Africa has remained below US\$ 1 billion, in a period in which FDI in Latin America has ranged between US\$ 3.5 billion and 14 billion. Because of the small size of the domestic market, inadequate infrastructure, falling world prices for private commodities and, in some cases, political instability, Sub-Saharan Africa has failed to attract much FDI. The bulk of external resource flows into the region is accounted for by grants and official loans, with FDI accounting for only 12 per cent of the total in 1993 (UNCTAD, 1995). Experience in other regions has shown that investors chose countries with stable political and economic environments. In this regard, Africa faces the multiple challenge of deepening or restoring macro-economic stability to help improve the general investment climate. By reducing uncertainty, macro-economic stability allows investment and savings decisions to be made in a manner consistent with underlying economic fundamentals, thereby promoting an efficient allocation of resources. Macro-economic stability also boosts confidence, which can encourage domestic investment and the inflow of foreign capital.

What does not appear to have received much scholarly attention is that not all FDI is equally beneficial. Historical and empirical evidence suggests that it is 
not so much the quantity of foreign investment that counts, but the nature of the investment and the sorts of linkages that are established with the local economy. In Africa, however, FDIs are seen as the answer to all developmental problems. This is because both aid and loan financing have proved unsuccessful. The first has created dependency and the second crippling and largely unpayable debts. So FDI is now offered as the solution to Africa's problems. To be sure, a certain amount of foreign investment is necessary, especially in the form of technology rather than hard cash. But this does not warrant the near religious belief in African countries that only FDIs can save them from the developmental crisis. Few have looked into the quality of FDI and what it does with the economy. Yash Tandon has argued that the extent to which FDI can help national development depends on the degree of control the country's government can exercise over the conditions and direction of the entry and operation of FDI. This ability of African and Third World countries is whittling away (Tandon, 1997: 52).

\section{The Challenge of Information Technology}

One other aspect of the globalising challenge facing Africa is in the field of information technology. It has been argued that if Africa fails to adjust successfully to the information society of the future, the continent's competitiveness will be severely disadvantaged in the emerging global economy. Globalisation has produced a proliferation of applications requiring a diverse range of communication technologies. Convergence and cost reduction have created opportunities for leapfrogging.

On the other hand, while the new information infrastructure opens up new opportunities, African countries lag far behind countries in Asia and Latin America in using information technology to spur development. South Africa (35th) and Egypt (51st) are the only African countries which are "able to absorb new technologies in the information age", according to The World Times Information Imperative Index (Amoako, 2000: 109). South Africa is the sole African country on The Economist's indicative list of countries effectively using information technology. As Wangwe and Musonda conclude, the marginalisation of Africa in terms of IT has occurred through an inability sufficiently to increase the stock of IT hardware in Africa; the low capacity to develop appropriate software; the ineffectiveness and unreliability of the telecommunications systems, a situation that is aggravated by their unequal distribution between and within countries, especially between urban and rural areas; and a lack of skill in developing and making effective use of IT (Wangwe \& Musonda, 1998: 157).

Closely related to this is the challenge posed by the shift towards technology and knowledge-based production. With increasing globalisation, the pattern of production is also shifting away from traditional mass production based on the use 
of cheap labour and raw materials, to production based on knowledge and advanced technology. The dawn and advance of information and communication technology have shrunk time and space, and facilitated the conversion of the entire world into one market place. This system of knowledge and technology based production calls for a more skilled and educated labour force. Needless to say that as African countries generally lag behind in this invaluable human resources, they face the challenge of losing out in the intensifying global competition.

\section{The Challenge of Regional Trading Arrangements}

Alongside globalisation and its accompanying effects, a shift towards regionalism is also occurring, posing another kind of challenge to Africa. This means that the world has seen at least as much fracturing as merging, as analysed by Sideri and Fischer in their recent studies (Sideri, 1997: 38-82; Fischer, 1998: 164-170). Despite the multilateral agreements reached under the Uruguay Round, the growth of regional trading arrangements (RTAs) has accelerated, with new RTAs being established, the membership of existing RTAs expanded, and formal links established between different RTAs. African countries are not included in the major RTAs, such as the European Union (EU) and North American Free Trade Agreement (NAFTA), which encompass their major exports markets. This has potentially important implications for the African countries.

The creation of an RTA entails the granting of preferential market access to its own members, and hence discrimination against non-members. Africa and other developing countries therefore stand to suffer a relative erosion of the terms of market access in their major export markets as a result of the growth of RTA, covering these markets, with the danger that their exports will lose market shares to exports originating from within the RTA. African countries will be in an especially vulnerable position if competing trade blocs turn inward looking, with each adopting protectionist policies towards non-members. On the whole, the emergence of the EU and other regional economic blocs in North America and the Pacific Rim is likely to diminish Africa's access to export commodity markets by raising the average level of protectionism in the advanced countries, stiffen export competitiveness, cause further substitution for Africa's commodity exports and impose losses in terms of trade, higher costs of imports and reduced export earnings from those markets (Asante, 1997: 119-125).

Although African countries are involved in a number of RTAs in their own regions (Economic Community of West African States [ECOWAS], Common Market for Eastern and Southern Africa [COMESA] and the Southern African Development Community [SADC] being among the largest of these groupings), 
the general experience of these RTAs has been disappointing in terms of the levels of intra-regional trade generated by these arrangements. The exports of the member countries of each of the three major African RTAs (COMESA, ECOWAS and SADC) to their fellow RTA members as a proportion of their total exports to the world declined over 1980-1990. ECOWAS recorded the largest decline of about 7 percentage points, followed by SADC of almost 3 percentage points, and COMESA by 2.5 percentage points (UNCTAD, 1996: 77).

The preceding section has highlighted the series of challenges, which the current course of global economic developments poses to Africa. African industries are exposed to stronger competition to which they lack the resources to respond effectively. The markets for their primary commodity exports are being further eroded through increased competition from non-LDC exporters and by the increased use of substitutes for raw materials. The concentration of private capital in RTAs, which comprise mostly the developed countries and the more dynamic developing countries, has intensified, with African and other less developed countries facing even greater difficulties in attracting FDI. The long-term opportunities of the Uruguay Round notwithstanding, some of its agreements pose a number of potential problems for African countries in the short-term, including preference erosion, tariff escalation and higher food import costs.

The fact that increased competition in global markets poses dangers for the economies of African countries reflects the very weak supply capacities in these countries. There is a lack of entrepreneurial and managerial skills, technological capacities are very poorly developed, the physical infrastructure is inadequate, the provision of support services, such as finance and marketing, is often very costly or unavailable, and labour productivity is slow. Consequently, Africa faces the critical problem of building its competitiveness in an atmosphere of progressive multilateral and regional liberalisation of world trade, increasing globalisation of production and rapid changes in technology. The continent must therefore develop an effective response to these changes in order to participate in the global trends that are going to shape the future of international economic relations.

\section{AN AGENDA FOR ACTION}

Although the specific policy requirements of individual African countries in meeting the challenges of globalisation will differ, it is, however, possible to identify a number of key areas which policy should address in most sub-Saharan African countries. In this regard, the following policy responses have been identified. 


\section{(i) Promote trade and investment}

Trade and investment are important vehicles for integrating Africa into the global economy and reaping benefits which accrue from it. A policy framework to promote increased investment in Africa must address issues relating to the political climate; a conducive economic policy framework; increased public savings and investment; increased private savings; attracting foreign investment; and enhanced regional cooperation and integration. The present strategy in many African countries of striving to make the local environment attractive, and providing a wide range of incentives to foreign investors, is only part of the question. Experience suggests that it will not go very far without substantial improvement in infrastructure, in particular transport and communications, and reliable power supplies.

With regard to trade expansion, Africa must embark on a more dynamic course marked by increased participation in world trade and a more purposeful engagement in international exchange of resources. Among the key elements to be identified to boost Africa's trade should include: reduction of transactions costs, including efficient physical and service infrastructures; diversification of products and markets; incentive regimes for exporters, including strategies to encourage small producers; institutional capacity-building for improved marketing and export promotion; trade financing; access to inputs at world market prices; strengthening negotiating capacities, both at the level of indigenous business as well as for governments' effective participation in the WTO multilateral trading system; and strengthening regional and sub-regional cooperation and integration aimed at boosting intra-African trade.

\section{(ii) Explore new opportunities in trade}

There is the need for African countries to actively explore areas where there may be growing opportunities for expanding their exports of goods and services, and take advantage of the opportunities provided by tariff reductions and better market access under the Unuguay Round on the one hand, and of growing import demand in large scale integration systems derived from their growth prospects on the other. In this connection, export promotion efforts to target the following objectives, among others, would be required:

- geographical diversification of trade towards rapidly growing markets, including developing countries in South East Asia and Latin America;

- exploiting new market opportunities in traditional agricultural sectors as well as processing industries;

- diversification of industrial exports; and

- exploiting new opportunities in services. 


\section{(iii) Accelerate African integration process}

While the proliferation of trading blocs is without doubt a global phenomenon, in Africa, the trading blocs are particularly important as a measure to contain and mediate competitive global pressures, which national policy resources cannot effectively handle. The rationale is that African countries, acting individually, cannot survive the vicious forces of globalisation in order to access the attendant benefits and minimise its costs. Regionalism, particularly in Africa, is thus seen as "the human face of globalisation which makes it the only space where liberalisation is suitable economically and politically" (Sideri, 1999: 170).

New initiatives in the process of African economic cooperation and integration should involve, among others, the following:

- speeding up the liberalisation provisions of the African economic communities in order to achieve the objectives of complete liberalisation of intra-African trade;

- promoting new efforts to achieve the harmonisation of macro-economic policies at the subregional level;

- encouraging strong political commitment of the African Govemments to advance integration towards common objectives and to give regional economic cooperation and integration a central role in the activities of governments.

\section{(iv) Bring information age to Africa}

To be able to benefit most fully from the emerging information age, Africa requires an action framework to build information and communications infrastructure at the national level as well as to improve regional inter-connectivity and to provide gateways to international telecommunications networks (Amoako, 2000: 99). To this end, there is the need to create enabling environments for an information society by liberalising information and communications technology services and fostering intellectual property protection, privacy, and the free flow of information.

\section{Adopt selective integration}

As far as economic development in African countries is concerned, the "first best" policy with respect to liberalisation and globalisation is not to seek rapid and close integration but rather to define careful policies of selective integration or what has been called strategic integration. Although dynamic gains can flow from integration with the world economy, it should be pointed out that these can only be realised by active government policies and if integration is patterned and timed to achieve clearly defined objectives. Put differently, national govern- 
ments can exercise more discretion when adopting policies of liberalisation. A selective approach to the global market would follow the example of most East Asian economies - with some time-bound, performance-related protection for potentially viable industries, some industrial intervention and some management of foreign direct investment.

\section{Invest in people}

Africa's future economic growth will depend less on its natural resources, which are being depleted and are subject to long-run price declines, and more on its labour skills and its ability to accelerate a demographic transition. To this end, as growth in today's information-based world economy depends on a flexible, educated, and healthy workforce to take advantage of economic openness, policies be adopted to contribute towards:sustaining political commitment to the poor; achieving universal primary education; eliminating gender disparities in education; achieving universal access to reproductive health services.

\section{Improve governance}

As better governance is a development imperative for most African countries, African Governments are constrained to initiate policies towards good governance that should aim at achieving what has been described as the "three Es":

- empower citizens to hold governments accountable through participation and decentralisation;

- $\quad$ enable governments to respond to new demands by building capacity;

- enforce compliance with the rule of law and greater transparency.

Effective governance is the foundation for sustainable development and poverty reduction and improved human well-being. This entails a state that, inter alia, respects the rule of law, ensures peace and stability, and enables full participation of citizens. In particular, the importance of transparent and accountable public engagement systems should be underscored. A dialogue on govemance in Africa will allow the people of Africa to share lessons and experiences, identifying capacity needs and best practices.

\section{CONCLUSION: AFRICA'S PROSPECTS}

Despite the daunting challenges, globalisation does offer a window of opportunity for African states. Competition, open market policies and globalisation are a reality in world economy today. Even though the benefits are not evenly distributed, African states have not been complete losers. They have enjoyed higher growth through the pursuit of market-oriented policies. Competition is also 
gradually exposing African economies to the discipline of the market place. They are moving up the learning curve. The market reforms and structural adjustment policies have brought about rationalisation and increased efficiency of many sectors of African economies. Countries, which have been able to undertake and sustain those reforms, have benefited from expanded trade opportunities and growth.

More significantly, an African renaissance is unfolding before our eyes. Most countries, throughout most of their years of independence, have been ruled by autocratic leaders autocratic because, whether enlightened or not, they stood above the law. Today, the rule of law is asserting itself. The sharp rise in political participation opens the way for greater public accountability and pressure from civil society for better management of public resources. Today's African leaders are more focused on proper economic management than many of their predecessors, and they have the maturity to address weaknesses of previous policies. These are crucial developments, because the fate of Africa in this new century will be determined not by outsiders, but by Africans. In this regard, we should welcome the Millennium Partnership for the African Recovery Programme (MAP, 2001) led by Presidents Mbeki of South Africa, Obasanjo of Nigeria and Boutefilka of Algeria, and the OMEGA Plan (OMEGA, 2001) proposed by President Wade of Senegal, which was presented in Sirte, Libya, in March 2001, to the African Heads of State and Government. The two major initiatives, which are being rationalised into a single African initiative to be operationalised by the United Nations Economic Commission for Africa's Compact for African Recovery (ECA, 2001), would provide an appropriate framework for meeting the challenges of African development. Together, these recent initiatives would provide the necessary political vision, momentum and implementation modalities for Africa to achieve the necessary conditions for transforming its prospects.

\section{REFERENCES}

1 AMOAKO, K.Y. (2000) Perspectives on Africa's Development, United Nations Publication, United Nations, New York.

2 ASANTE, S.K.B. (1997) Regionalism and Africa's Development: Expectations, Reality and Challenges, Macmillan Press, London.

3 CHINERY-HESSE, M. (1997) "Globalisation, African Market and the Challenges for Governance", in Proceedings of the African Leadership Forum International Conference on the theme "Africa on the Eve of the 21 st Century", Maputo, Mozambique.

4 ECONOMIC COMMISSION FOR AFRICA (2001) Compact for African Recovery, Addis Ababa. 
5 FISHER, B. (1998) "Globalisation and the Competitiveness of Regional Blocs", Intereconomics, July/August: 164-1705.

6 GAMANI, C. (1999) "The Challenge of Globalisation", in Walter Fernandes and Anupama Dutta (eds.), Colonialism and Globalisation: Five Centuries After Vasco da Gama, New Delhi, Indian Social Institute.

7 HELD, D. \& MCGREW, A. (2001) "Globalisation", in Joel Krieger (ed.) The Oxford Companion to Politics of the World, Oxford University Press.

8 NEL, P. (1999) "Globalisation and South African Elite", Global Dialogue 4: 1 .

9 NEVIN, T. (2000) "Africa and the Globalisation Conundrum", Africa Business: 258 .

10 OMEGA PLAN (2001) Dakar, Senegal.

11 ONITIRI, H.M.A. (1995) Regionalism and Africa's Development, UNCTAD/TTD/18.

12 OTABIL, B.A. (2000) "Globalisation: Which Way Forward?", West Af. rica, 2-8 October.

13 SIDERI, S. (1997) "Globalisation and Regional Integration", European Journal of Development Research, 9, 1: 38-82.

14 STREETEN, P. (1998) "Globalisation: Threat or Salvation?", in A.S. Bhalla (ed.) Globalisation, Growth and Marginalisation, Macmillan Press, London, and St. Martin's Press, New York.

15 TANDON, Y. (1997) "Africa in the Globalisation Process", in Proceedings of the African Leadership International Conference on the theme "Africa on the Eve of the 21 st Century", Maputo, Mozambique.

16 THE MILLENNIUM PARTNERSHIP FOR THE AFRICAN RECOVERY PROGRAMME (2001) Pretoria, South Africa.

17 UNCTAD (1996) The Least Developed Countries 1996 Report, TD/B/42 (2), 11, UNCT AD/LDC.

18 UNCTAD (1995) Trade and Development Report, Geneva, UNCTAD.

19 UNDP (1998) Human Development Report 1998, New York: Oxford University Press: 128-130.

20 WANGWE, S.M. \& MUSONDA, F. (1998) "The Impact of Globalisation on Africa" in A.S. Bhalla (ed.) Globalisation, Growth and Marginalisation London: Macmillan Press and New York: St. Martin's Press.

21 WORLD BANK (2000) Can Africa Claim the 21st Century? Washington, D.C.: $7,9-10$ 